\title{
Temporal and spatial patterns of wetland extent influence variability of surface water connectivity in the Prairie Pothole Region, United States
}

\author{
Melanie K. Vanderhoof $•$ Laurie C. Alexander • M. Jason Todd
}

Received: 27 April 2015/Accepted: 28 September 2015/Published online: 6 October 2015

(C) The Author(s) 2015. This article is published with open access at Springerlink.com

\begin{abstract}
Context Quantifying variability in landscape-scale surface water connectivity can help improve our understanding of the multiple effects of wetlands on downstream waterways.

Objectives We examined how wetland merging and the coalescence of wetlands with streams varied both spatially (among ecoregions) and interannually (from drought to deluge) across parts of the Prairie Pothole Region.

Methods Wetland extent was derived over a time series (1990-2011) using Landsat imagery. Changes in landscape-scale connectivity, generated by the physical coalescence of wetlands with other surface water features, were quantified by fusing static wetland and stream datasets with Landsat-derived wetland extent maps, and related to multiple wetness indices. The usage of Landsat allows for decadal-scale analysis, but limits the types of surface water connections that can be detected.
\end{abstract}

\section{K. Vanderhoof $(\bowtie)$}

U.S. Geological Survey, Geosciences and Environmental Change Science Center, P.O. Box 25046, DFC, MS980,

Lakewood, CO 80225, USA

e-mail: melvanderhoof@gmail.com;

mvanderhoof@usgs.gov

\section{C. Alexander · M. J. Todd}

U.S. EPA Office of Research and Development, National Center for Environmental Assessment, 1200 Pennsylvania Ave. NW, Washington, DC 20460, USA
Results Wetland extent correlated positively with the merging of wetlands and wetlands with streams. Wetness conditions, as defined by drought indices and runoff, were positively correlated with wetland extent, but less consistently correlated with measures of surface water connectivity. The degree of wetlandwetland merging was found to depend less on total wetland area or density, and more on climate conditions, as well as the threshold for how wetland/upland was defined. In contrast, the merging of wetlands with streams was positively correlated with stream density, and inversely related to wetland density.

Conclusions Characterizing the degree of surface water connectivity within the Prairie Pothole Region in North America requires consideration of (1) climate-driven variation in wetness conditions and (2) within-region variation in wetland and stream spatial arrangements.

Keywords Wetland inundation - Wetland-stream connectivity - Geographically isolated wetlands . Prairie Pothole Region · Landsat · Interannual variability

\section{Introduction}

Wetland systems provide many critical ecological functions including groundwater recharge, floodwater retention, lotic base flow contributions, biogeochemical processing, water quality improvement, and 
wildlife habitat (Mitsch and Gosselink 2000; Whigham and Jordan 2003; Millennium Ecosystem Assessment 2005; Brauman et al. 2007). Federal jurisdiction over wetlands, under the Clean Water Act, is informed by several court decisions including the U.S. Supreme Court Decisions in SWANCC v. U.S. ACE (531 U.S. 159 (2001)) and Rapanos v. United States (547 U.S. 715 (2006)). These decisions indicated that wetlands having a "significant nexus" with "navigable waters" may be jurisdictional under the Clean Water Act (Leibowitz et al. 2008). This has motivated research to determine the number and distribution of wetlands that could be jurisdictional (Tiner 2003; Frohn et al. 2012; Lane et al. 2012), their spatial relationships to streams (Lang et al. 2012), and the ecosystem functions that these wetlands provide (Whigham and Jordan 2003; Comer et al. 2005; Lane and D'Amico 2010).

The identification of potentially jurisdictional wetlands has focused on the subset of wetlands lacking obvious surface water connections (Tiner 2003; Lane et al. 2012). These wetlands are commonly referred to as potentially geographically isolated wetlands or pGIWs, although this phrase is controversial and can be misleading (Mushet et al. 2015). Although most efforts to identify these wetlands have relied on static wetland datasets (Tiner 2003; Lane et al. 2012), the actual degree of surface water connectivity varies among wetlands and for many can be expected to fluctuate over time (Leibowitz and Vining 2003; Winter and LaBough 2003; Shook et al. 2015).

Wetlands have the capacity to store precipitation and hydrologic inflows (Ludden et al. 1983; De Laney 1995), reducing peak stream flows and downstream flooding by temporarily reducing the contributing area for a watershed's outlet (Philips et al. 2011; Shaw et al. 2013). However, under wet conditions many of these same wetlands intermittently exchange or contribute water to other wetlands and/or streams through temporary overland or shallow groundwater flows, ephemeral flows in channels, and/or the merging of wetland waters in low relief areas (Rains et al. 2006; Cook and Hauer 2007; Rains et al. 2008; Sass and Creed 2008; Kahara et al. 2009; Wilcox et al. 2011). Connectivity between wetlands within wetland complexes that eventually "fill and spill" (Tromp-van Meerveld and McDonnell 2006) into streams can result in highly non-linear relationships between basin water storage capacity and stream contributing area (Philips et al. 2011; Shaw et al. 2012, 2013).
The Prairie Pothole Region (PPR) in north-central North America contains a high density of depressional wetland features, a consequence of glacial retreat (Flint 1971), and provides habitat for large populations of waterfowl (Sorenson et al. 1998). Hydrological research efforts within the region have focused on quantifying the effect of inter- and intra-annual variations in water levels or wetland areas on waterfowl habitat availability (Johnson et al. 2004; Kahara et al. 2009; Niemuth et al. 2010; Liu and Schwartz 2011). However, few studies have explicitly examined how interannual variability in wetland area influences hydrological interactions between individual wetlands or between wetlands and streams within this region (Leibowitz and Vining 2003; Kahara et al. 2009).

In this study we quantified how surface water interactions between wetlands and streams varied both spatially and interannually at the landscape scale across the PPR. Our aim was to advance previous efforts using the static National Wetland Inventory (NWI) dataset to map wetlands lacking obvious surface water connections (Tiner 2003; Lane et al. 2012), and more recent efforts to map climatically variable biological connectivity among wetlands (McIntyre et al. 2014; Ruiz et al. 2014). Our objectives were to quantify (1) the interannual variation in wetland extent, (2) how spatial and interannual changes in wetland extent translate into variability in observed wetland-wetland and wetland-stream connectivity, and (3) how interannual variability in waterbody merging and connectivity is related to climate conditions and stream flow. Exploring surface water dynamics in regions with a high density of wetlands is critical to improving our understanding of how wetlands interact with downstream waters. Quantifying temporal and spatial variability in the degree of landscape-scale connectivity will inform our predictions of how climate change and human activities influence the distribution of surface water and magnitude of stream flow.

\section{Methods}

Study area and ecoregions

Ecoregions were used as the unit of analysis across two, non-adjacent, Landsat path/rows (Path 29, Row 29 and Path 31, Row 27) within the United States 
portion of the PPR (Fig. 1). Spatial patterns in deposited glacial material following the retreat of the Laurentide icesheet continue to influence the topography and drainage systems across the PPR. The selected ecoregions correspond approximately to the extent of physiographic regions and captured the wide diversity of wetland and stream densities and configurations across the study area (Table 1). Ecoregion extent was based on the U.S. Environmental Protection Agency Level IV Ecoregion definitions (Omernik and Griffith 2014), and included (1) the Drift Plains, (2) the Missouri Coteau, (3) the Prairie Coteau, (4) Lowlands (included the Big Sioux Basin, James River
Lowland and Loess Prairie ecoregions), and (5) the Des Moines Lobe (included the Minnesota River Prairie and Tewaukon/Big Stone Stagnation Morraine ecoregion) (Fig. 1). Landcover across both path/rows was dominated by cultivated crops ( 51 and $62 \%$ for p31r27 and p29r29, respectively), hay/pasture (16 and $10 \%$ for p31r27 and p29r29, respectively), and herbaceous (14 and $13 \%$ for p31r27 and p29r29, respectively) (Homer et al. 2015). Summer (JuneAugust) (19.9 and $20.9{ }^{\circ} \mathrm{C}$ ) and winter (DecemberFebruary) $\left(-9.2\right.$ and $\left.-8{ }^{\circ} \mathrm{C}\right)$ temperatures (1981-2010) were similar between p31r27 and p29r29, while precipitation was lower in p31r27
Fig. 1 Location of Landsat path/rows, ecoregion divisions, and stream gauge locations

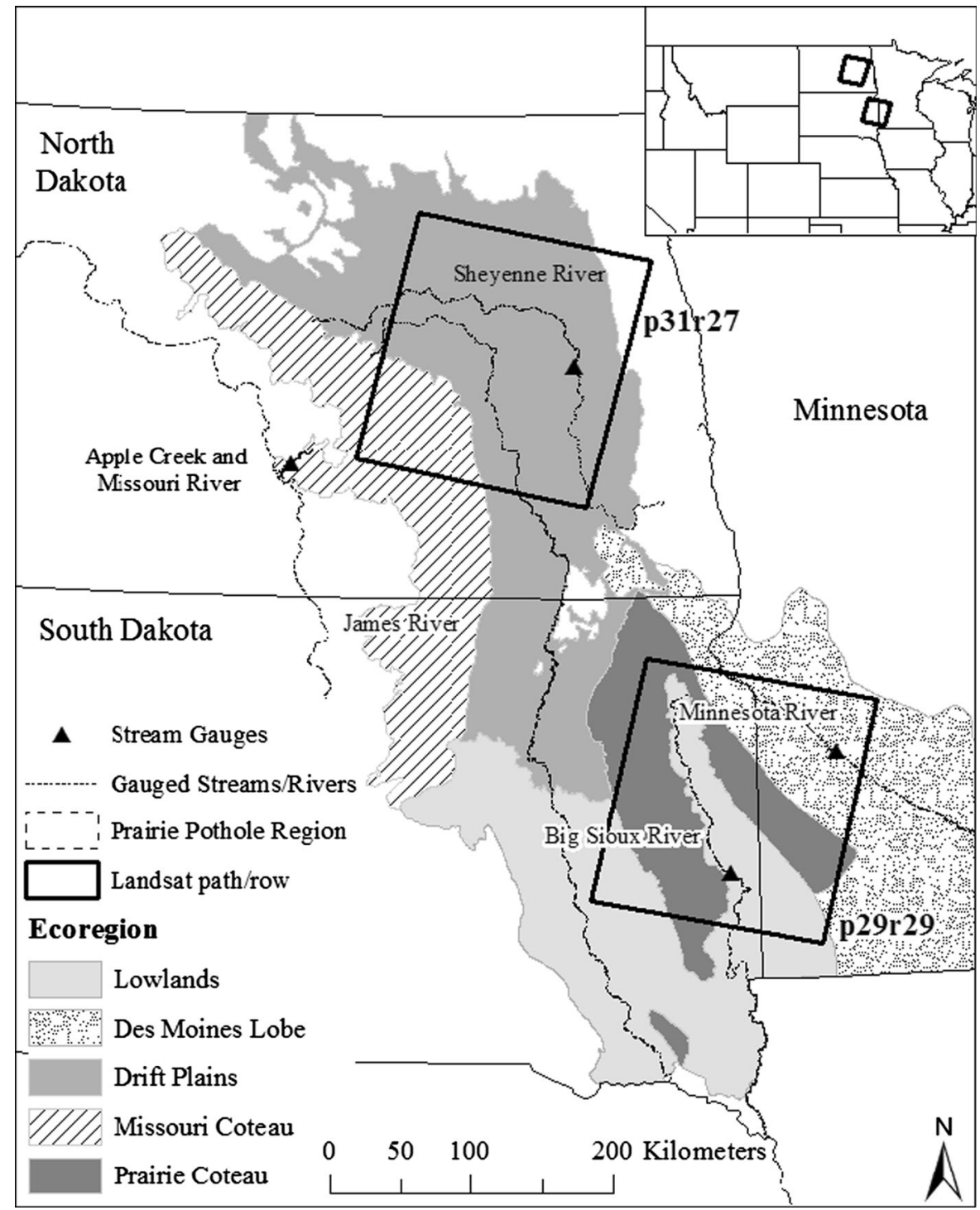


Table 1 National Wetlands Inventory (NWI) wetland and National Hydrography Dataset (NHD) stream density by ecoregion

\begin{tabular}{|c|c|c|c|c|c|c|c|}
\hline Ecoregion & Size (ha) & $\begin{array}{l}\text { Annual Precip } \\
(1981-2010) \\
\text { Normal (mm) }\end{array}$ & $\begin{array}{l}\text { NHD stream } \\
\text { density }\left(\mathrm{m} \mathrm{ha}^{-1}\right)\end{array}$ & $\begin{array}{l}\text { NWI wetland } \\
\text { area }\left(\mathrm{m}^{2} \mathrm{ha}^{-1}\right)\end{array}$ & $\begin{array}{l}\text { NWI wetland } \\
\text { count (\# per ha) }\end{array}$ & $\begin{array}{l}\text { WSvc/nc } \\
\text { count }(\%)\end{array}$ & $\begin{array}{l}\text { WSvc/nc } \\
\text { area }(\%)\end{array}$ \\
\hline Lowlands & 887,232 & 653 & 13.4 & 485.3 & 0.06 & 80.0 & 40.0 \\
\hline Des Moines Lobe & 824,612 & 648 & 10.1 & 616.6 & 0.02 & 83.4 & 31.6 \\
\hline Prairie Coteau & $1,215,080$ & 646 & 9.7 & 1184.8 & 0.07 & 88.4 & 41.1 \\
\hline Drift Plains & $2,337,680$ & 507 & 4.4 & 1120.6 & 0.13 & 97.4 & 67.1 \\
\hline Missouri Coteau & 524,552 & 484 & 3.0 & 1369.7 & 0.11 & 96.9 & 75.1 \\
\hline
\end{tabular}

WSvc/nc (wetlands variably connected or not connected to a stream) were calculated as the NWI wetlands that did not intersect the NHD stream layer (including stream polygons and $14 \mathrm{~m}$ stream buffer). Precipitation data represent spatially averaged PRISM 30 year annual normals (1981-2010)

(496 $\left.\mathrm{mm} \mathrm{year}^{-1}\right), \quad$ relative to $\mathrm{p} 29 \mathrm{r} 29$ $\left(649 \mathrm{~mm} \mathrm{year}^{-1}\right)$ (1981-2010) (NOAA NCDC 2014).

Image processing

Seventeen Landsat images for p29r29 and sixteen Landsat images for p31r27 ( $<10 \%$ cloud cover) were selected to coincide with snow-free conditions. Cloud cover was a significant obstacle for image selection, particularly during the spring months. The time series (1990-2011) captured a wide range of interannual hydrological conditions (Table 2; Fig. 2), but was not expected to capture peak annual conditions such as specific rain events that could have resulted in shortduration (hours or days) connection events between wetlands and streams. Indices used to characterize wetness conditions are described in "Additional datasets," below. The images were atmospherically corrected and converted to surface reflectance values using the Landsat Ecosystem Disturbance Adaptive Processing System (LEDAPS) (Masek et al. 2006). The per pixel fraction water was derived using the Matched Filtering algorithm in the ENVI software package (Exelis Visual Information Solutions, Inc, Herndon, VA), then thresholded into inundated, saturated and non-saturated cover classes using a threshold analysis. The Matched Filtering algorithm is a partial unmixing method designed to detect the abundance of a known endmember (e.g. water) against a composite of unknown background endmembers (vegetation, soil, etc.) (Turin 1960), and has been used previously to identify depressional wetland features at a sub-pixel scale (Frohn et al. 2012). Additional steps taken to reduce error included applying a minimum noise fraction transformation (Green et al. 1988), linearly stretching the output values, and masking out impervious surfaces, defined as low, medium and high density development (Homer et al. 2015), to reduce false positives.

The algorithm output maps representing the fraction water were then classified into inundated (inun), saturated (sat), and non-saturated cover using a threshold analysis. The mean fraction water was derived for five cover classes, with the aim to distinguish between water and vegetation: (1) inundation (i.e. open water) (258 total points), (2) saturation (i.e., visibly wet soil adjacent to open water features) (239 total points), (3) wet channel-swale features (261 total points), (4) non-photosynthetic vegetation (167 total points), and (5) photosynthetic vegetation (183 total points). These 1108 points were randomly selected and distributed across the two Landsat path/rows. Cover classes were identified from $1 \mathrm{~m}$ resolution National Agricultural Imagery Program (NAIP) imagery representing three dates per Landsat path/row (April 30, 2004, October 13, 2006 and October 8, 2010 for p29r29; July 1, 2004, October 5, 2004, and September 9, 2006 for p31r27). The inundation threshold represents a high confidence of surface water and was derived using the mean differences in the per pixel fraction water between the inundation and saturation cover classes. The saturated threshold was derived using the mean differences in the fraction water between the saturation and photosynthetic vegetation cover types. This second, more inclusive threshold, allowed for the inclusion of more mixed pixels (e.g. shallow water or shallow sub-surface flow, wetland edges, and vegetated water) (e.g. Sass and Creed 2008), a critical problem in using a moderate resolution source of imagery to detect inundation in a landscape with a 
Table 2 Landsat TM images utilized in the analysis and corresponding monthly Palmer Hydrological Drought Index (PHDI) and Standardized Runoff Index (SRI) values

\begin{tabular}{|c|c|c|c|c|c|c|c|}
\hline Path/row & Landsat TM image & PHDI & SRI & Path/row & Landsat TM image & PHDI & SRI \\
\hline p29r29 & 10-Мау-1990 & -3.55 & -1.68 & p31r27 & 9-Jun-1990 & -4.12 & -1.74 \\
\hline p29r29 & 13-Мay-1991 & -0.69 & -0.86 & p31r27 & 12-Jun-1991 & -2.45 & -1.75 \\
\hline p29r29 & 15-Мау-1992 & -1.15 & -0.53 & p31r27 & 27-Apr-1992 & -1.93 & -0.72 \\
\hline p29r29 & 23-Sep-1993 & 6.86 & 2.28 & p31r27 & 26-Oct-1994 & 7.03 & 0.52 \\
\hline p29r29 & 15-Oct-1995 & 6.37 & 0.84 & p31r27 & 27-Sep-1995 & 5.97 & 0.78 \\
\hline p29r29 & 14-Jun-1997 & 4.02 & 0.61 & p31r27 & 14-Jul-1997 & -0.085 & 0.82 \\
\hline p29r29 & 30-Apr-1998 & 2.77 & -0.13 & p31r27 & 1-Мay-1999 & 2.01 & 0.89 \\
\hline p29r29 & 8-Мay-2001 & 4.47 & 1.40 & p31r27 & 9-Jul-2001 & 4.46 & 1.52 \\
\hline p29r29 & 19-Nov-2002 & -1.69 & -0.61 & p31r27 & 5-Oct-2004 & 4.38 & 0.17 \\
\hline p29r29 & 28-Apr-2003 & -2.01 & -0.97 & p31r27 & 18-Jun-2005 & 1.45 & 0.81 \\
\hline p29r29 & 1-Apr-2005 & 3.15 & -0.90 & $\mathrm{p} 31 \mathrm{r} 27$ & 9-Sep-2006 & -2.91 & -0.80 \\
\hline p29r29 & 4-Apr-2006 & 4.2 & -0.32 & p31r27 & 12-Sep-2007 & 2.41 & 0.19 \\
\hline p29r29 & 13-Oct-2006 & 2.3 & -0.13 & p31r27 & 1-Sep-2009 & 3.28 & 0.47 \\
\hline p29r29 & 15-Apr-2010 & 5.43 & 0.40 & p31r27 & 6-Oct-2010 & 6.43 & 0.52 \\
\hline p29r29 & 8-Oct-2010 & 9.63 & 2.37 & p31r27 & 5-Jul-2011 & 6.61 & 0.95 \\
\hline p29r29 & 5-Jun-2011 & 8.37 & 1.32 & p31r27 & 11-Sep-2011 & 8.92 & 1.49 \\
\hline p29r29 & 11-Oct-2011 & 5.88 & 0.59 & & & & \\
\hline
\end{tabular}

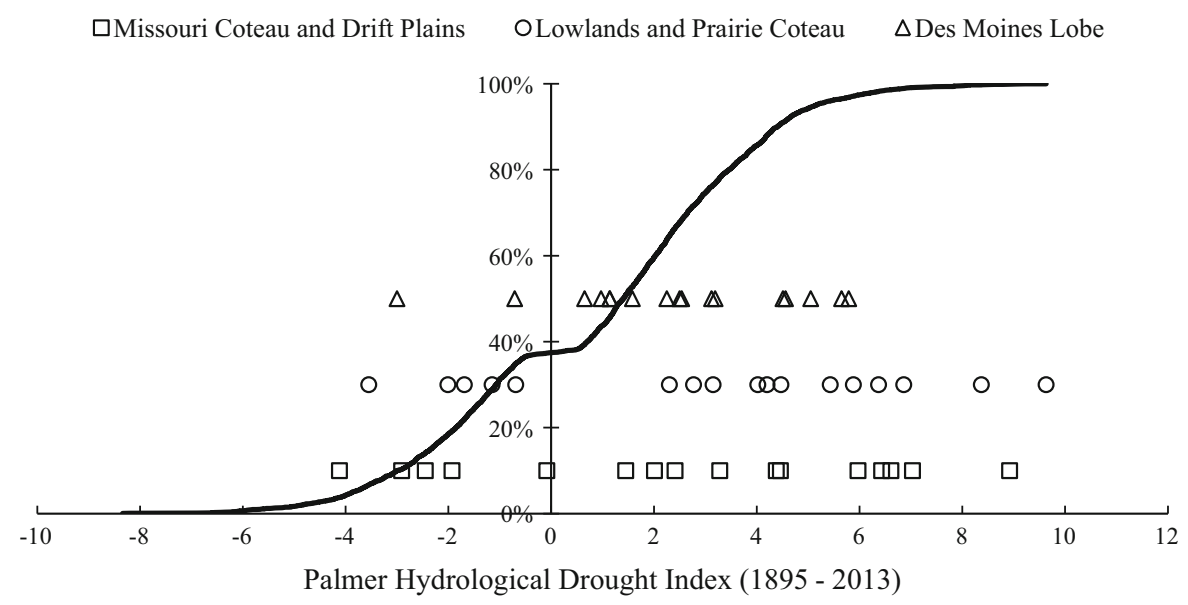

Fig. 2 The Cumulative Distribution Function (CDF) for monthly PHDI values from 1895 to 2013 averaged across the NOAA NCDC Division 5 in North Dakota, Division 7 in South Dakota and Division 7 in Minnesota (March to November). The

high density of small ( $<1$ ha) depressional wetlands. Most small (i.e. $\sim 3-10 \mathrm{~m}$ wide) channel-swale features represented a minor areal fraction of the Landsat pixel and on average were spectrally indistinguishable from non-saturated cover types. distribution of PHDI values for the time series of Landsat images used for each ecoregion is also shown (via triangles, circles, and squares). Ecoregions were paired if they were both represented by a single PHDI data division

Differences in the fraction water were larger between cover classes than between dates, justifying the application of thresholds across all dates and both path/rows. The outputs were inundation and saturation cover maps over the time series. 
Validation analysis

The inundation and saturation cover maps were validated using (1) a random point analysis; and (2) a minimum wetland size detection analysis. Patterns of inundation were first validated using 1500 points $(250$ points per image and same NAIP dates as threshold analysis). Outcomes (wetland/upland) were compared between NAIP and the Landsat derived wetland (inun and sat) maps. Producer accuracy is the probability that a pixel is classified as a wetland (or water) given that a wetland (or water) is present on the ground; user accuracy is the probability that a wetland is present given a pixel classified as a wetland. Overall accuracy (percent of all points correctly classified) was $96.5 \%$ (sat) and $95.3 \%$ (inun). The producer accuracy for wetlands was $94.6 \%$ (sat) and $77.9 \%$ (inun), while the user accuracy for wetlands was $88.4 \%$ (sat) and $98.3 \%$ (inun) (Table 3). A lower producer accuracy for inundation wetland maps was largely a consequence of mixed pixels being misclassified as upland due to the usage of a conservative threshold. To determine the minimum wetland size that was reliably detected, we used NAIP imagery from the same dates to randomly select a total of 421 NWI wetlands from $<0.1$ to 1 ha in size. Wetlands were selected that 1 ) were individual wetland features (i.e., not part of a larger wetland complex), and 2) showed at least some open water. Using the more inclusive saturation threshold, wetlands larger than 0.2 ha were reliably detected $(79 \%)$, while using the more conservative inundation threshold wetlands larger than 0.8 ha were reliably detected (70\% detected). The primary reason for this difference was that many smaller inundated features translated to mixed pixels in Landsat, resulting in a percentage of water high enough to be considered saturated but not inundated, and further supports our utilization of two thresholds. A comparison of wetland extent between NAIP imagery and Landsat in a wet and dry year are shown in Fig. 3. We note that areas classified as inundated and saturated are referred to as "wetlands" (including lakes and other open waters) in this analysis; however, the presence of standing water alone may not be sufficient to define a feature as a wetland as defined by Cowardin et al. (1979). Conversely, mapping only areas inundated with water may exclude areas that meet the Cowardin et al. (1979) definition of a wetland but do not contain open water at the time of the image, such as temporary or seasonal wetlands, or surrounding wet-meadow and shallow-marsh zones of more permanent wetlands.

\section{Additional datasets}

The National Wetland Inventory (NWI) dataset (USFWS 2010) was used as a static (non-changing) reference layer from which to compare interannual variation in wetland extent. This dataset is designed to
Table 3 Accuracy assessment for wetland maps, derived by comparing NAIP imagery against Landsat imagery, using both inundation and saturation thresholds

\begin{tabular}{|c|c|c|c|}
\hline & NAIP_Wetland & NAIP_-Upland & Total points \\
\hline \multicolumn{4}{|l|}{ Saturation map accuracy } \\
\hline Landsat-Wetland & 283 & 37 & 320 \\
\hline Landsat_-Upland & 16 & 1164 & 1180 \\
\hline Total & 299 & 1201 & 1500 \\
\hline Producer accuracy for wetland (\%) & 94.6 & & \\
\hline User accuracy for wetland (\%) & 88.4 & & \\
\hline Overall accuracy $(\%)$ & 96.5 & & \\
\hline Kappa statistic & 0.9 & & \\
\hline \multicolumn{4}{|l|}{ Inundation map accuracy } \\
\hline Landsat—Wetland & 232 & 4 & 236 \\
\hline Landsat_-Upland & 66 & 1198 & 1264 \\
\hline Total & 298 & 1202 & 1500 \\
\hline Producer accuracy for wetland (\%) & 77.9 & & \\
\hline User accuracy for wetland (\%) & 98.3 & & \\
\hline Overall accuracy $(\%)$ & 95.3 & & \\
\hline Kappa statistic & 0.8 & & \\
\hline
\end{tabular}



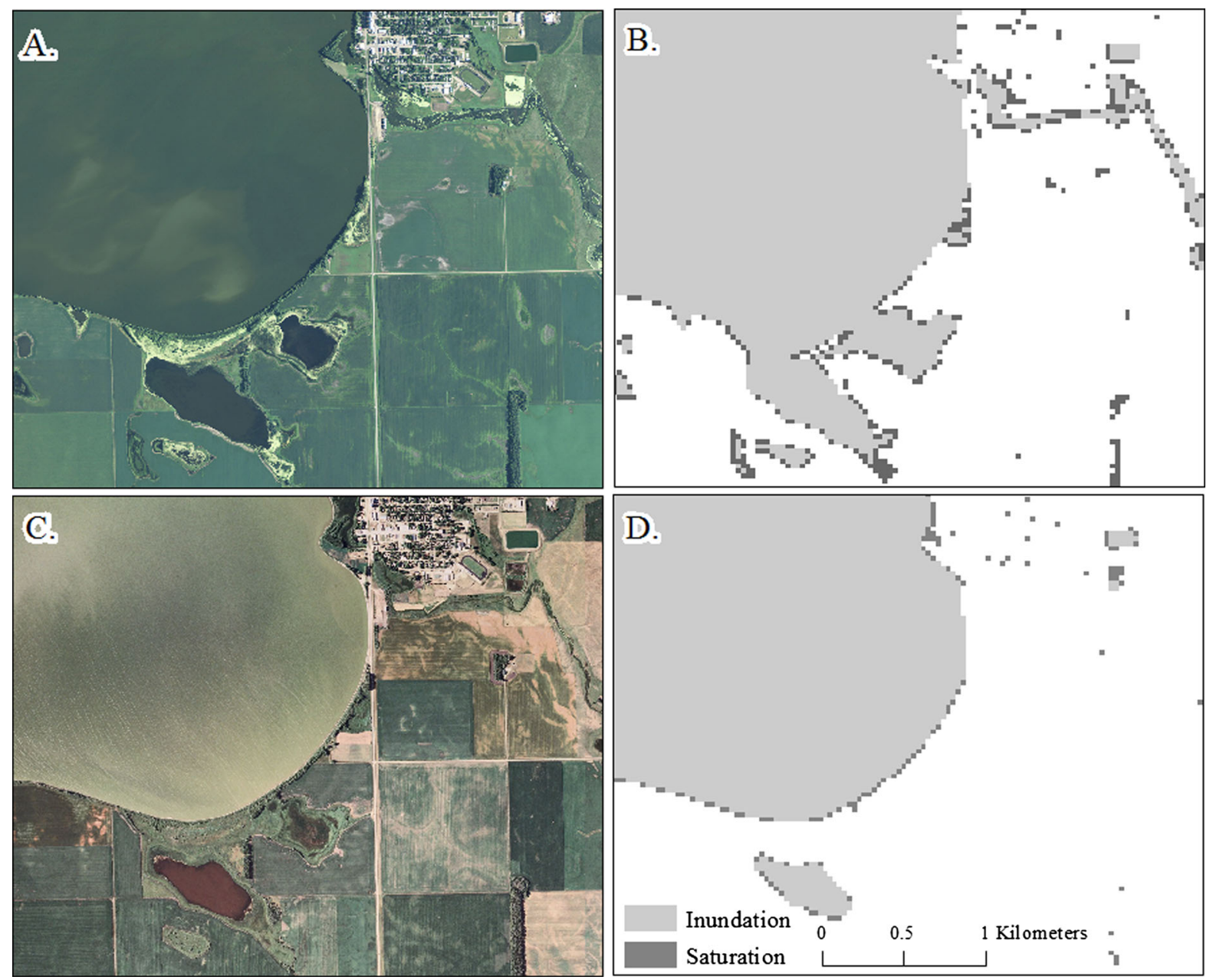

Fig. 3 Comparison of wetland extent between a NAIP imagery in fall 2010, b Landsat derived wetland extent in fall 2010, c NAIP imagery in fall 2006, and d Landsat derived wetland extent in fall 2006

represent wetland extent under "average" hydrological conditions (USFWS 2010), which allows for changes between "average" and "wet" to be captured, but limits our ability to capture changes between "dry" and "average" conditions. Wetland boundaries, internal to a single, continuous NWI wetland, were dissolved. Stream occurrence was defined by the high resolution National Hydrography Dataset (NHD) (1:24,000) (USGS 2013a). A stream buffer was applied $( \pm 14 \mathrm{~m})$ to account for the nationally reported digital inaccuracy in the lateral location of stream features within this dataset (USGS 2000). To account for the channel width of large river features, stream and river polygons included within NHD Area layer were merged with the buffered stream layer. NHD has been shown to inconsistently map ephemeral and intermittent streams and ditches (Lang et al. 2012; Fritz et al. 2013), therefore wetland-stream connectivity in headwater streams and agricultural areas should be assumed to be under-estimated by this analysis. Climate conditions were characterized using the monthly Palmer Hydrological Drought Index (PHDI), calculated from precipitation and temperature station data and interpolated at $5 \mathrm{~km}$ (NOAA NCDC 2014), and a monthly Standardized Runoff Index (SRI) $(4 \mathrm{~km} \times 5 \mathrm{~km}$ resolution) (Kingstse and Chen, written communication, 2014). The PHDI does not explicitly consider snow depth and snow melt, which results in a poor correlation between soil moisture and drought indices in spring months, when snowmelt is the dominant source of soil moisture (Dai et al. 2004). The SRI, in contrast, incorporates seasonal dynamics 
by predicting runoff from the North America Land Data Assimilation Systems (NLDAS), a land-surface model (Shukla and Wood 2008). Runoff $\left(\mathrm{mm}\right.$ month $^{-1}$ ) was also calculated from daily stream flow $\left(\mathrm{m}^{3} \mathrm{~s}^{-1}\right)$. Stream flow was obtained from four USGS gauges that best represented the outflow points (downstream from the Landsat path/rows) for each ecoregion over the entire time series (1990-2011): (1) the Sheyenne River near Cooperstown, North Dakota (USGS Gauge \#05057000) for the Drift Plains ecoregion, (2) Apple Creek near Menoken, North Dakota (USGS Gauge \#06349500) for the Missouri Coteau ecoregion, (3) the Big Sioux River near Brookings, South Dakota (USGS Gauge \#06480000) for the Prairie Coteau and Lowlands ecoregions, and 4) the Minnesota River at Montevideo, Minnesota (USGS Gauge \#05311000) for the Des Moines Lobe ecoregion (Fig. 1). Limitations in stream gauge locations meant that the stream gauge data provided a tertiary source of wetness conditions and were not intended to predict outflow from the entire ecoregion.

\section{Connectivity analysis}

Wetland-wetland and wetland-stream connectivity were quantified from the detection of physical intersections of surface water boundaries. The term "merging" in this analysis refers to the mechanism of physical connection occurring between features, while the terms wetland-wetland and wetland-stream connectivity refer to estimates of landscape-scale connectivity produced by merging of features. The resolution of Landsat can be expected to limit the detection of some types of connections, in particular narrow connections not documented by NHD, so that additional surface water connections likely occur that are not documented by this analysis. Wetland-wetland merging occurred when more than one NWI wetland was co-located within a single, continuous Landsatderived wetland (Fig. 4). Wetland-wetland connectivity was then defined as the percent of NWI wetlands that merged with at least one other NWI wetland in a single image. Wetland-stream connectivity (WSc/vc, i.e. wetlands connected or variably connected to streams) was defined as the percentage of NWI wetlands that merged with a stream in a single image. NWI wetlands were considered to be connected to (i.e. merged with) a stream if they (1) intersected the NHD stream layer (including stream polygons and buffer) (WSc) or (2) intersected a stream-connected patch of surface water, as mapped by Landsat (WSvc) (Fig. 4). This second group of wetlands (WSvc) are NWI wetlands that do not intersect the NHD stream layer directly, but merge with a stream under wetter conditions as a river floods, or a stream-connected

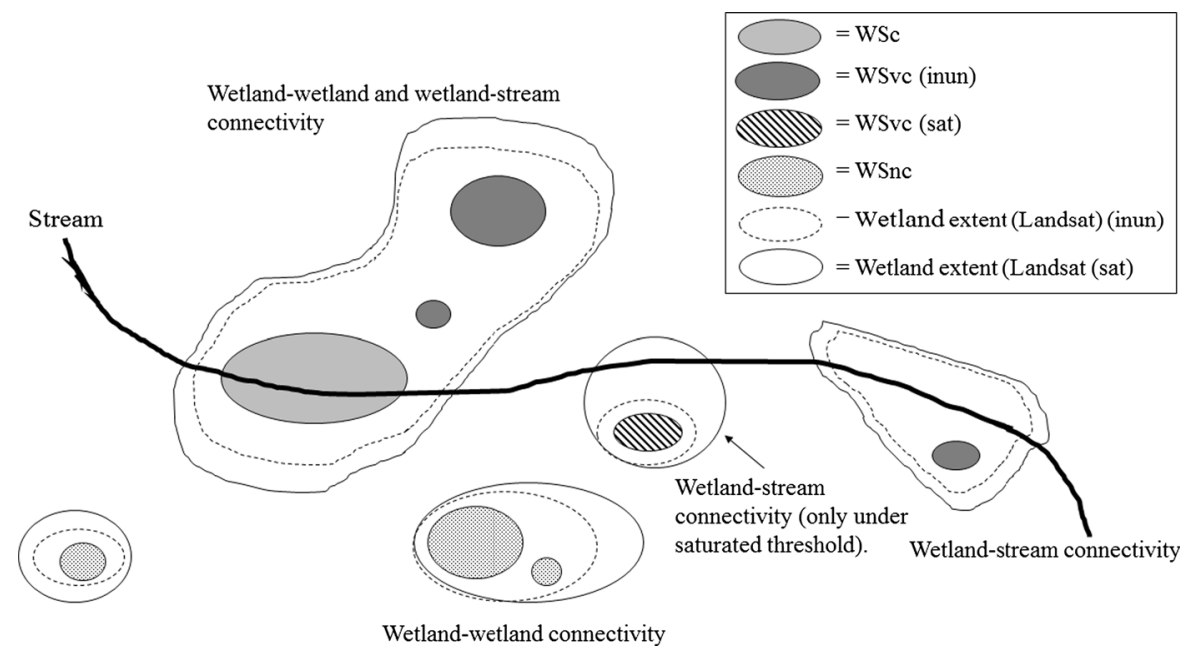

Fig. 4 A schematic showing NWI wetland classification, where WSc indicates an NWI wetland that intersects a stream, a WSvc indicates an NWI wetland that shows a variable connection to a stream, and a WSnc indicates an NWI wetland for which no connection to a stream was documented. Wetland- wetland connectivity occurs when more than one NWI wetland co-occurs within a single wetland, as defined by Landsat, while wetland-stream connectivity occurs when an NWI wetland intersects a stream or a stream-connected patch of surface water, as mapped by Landsat 
lake or wetland expands, subsuming or connecting nearby wetlands (Kahara et al. 2009). The term WSvc/ $\mathrm{nc}$ is used in this analysis instead of pGIW to refer to all NWI wetlands that do not intersect the stream polygons or stream buffer, and therefore includes all wetlands classified as WSvc. Wetland-wetland and wetland-stream connectivity were compared among ecoregions as well as over the time series using t-tests and linear regressions (R Core Team 2014).

This analysis aimed to measure surface water connections as defined above, and did not consider other mechanisms of surface (e.g. fill-and-spill, overland flow, channelized flows) or groundwater hydrologic connectivity. The moderate resolution of the Landsat imagery $(30 \mathrm{~m})$ was expected to influence (1) the number of small $(<1 \mathrm{ha})$ wetlands that could be individually mapped, and (2) the types of surface water connections among wetlands and streams that could be detected. We quantified the percentage of NWI wetlands detected by Landsat in a wet-period image (spring 2011). In this image, $28 \%$ (85\% of total NWI area) and $54 \%$ (94\% of total NWI area) of the NWI wetlands intersected with the stream layer and the Landsat inundated or saturated wetlands, respectively, across the five ecoregions. The average sizes of undetected NWI wetlands in the spring 2011 image were 0.22 and 0.15 ha for the inundated and saturated classes, respectively. For reference, one Landsat pixel $=0.09$ ha, meaning that undetected NWI wetlands were on average two to three pixels in size. Alternatively, many of these small wetlands could have been dry at the time of the Landsat image or converted to other land uses since the NWI dataset was derived $\sim 30$ years ago (Dahl 2014). To compensate for this source of error, estimates of wetlandwetland and wetland-stream connectivity were calculated from all NWI wetlands (detected and undetected); therefore, any NWI wetland that did not intersect the NHD stream layer (WSc) or a Landsatderived wetland (WSvc), remained a WSnc (or not connected) (acknowledging that wetlands are not "isolated;" Mushet et al. 2015).

Landsat imagery can also be expected to bias the analysis towards detection of surface water connections that occur through the expansion of relatively broad features such as river overflow into floodplains, increases in wetland water level that result in adjacent wetlands being subsumed or merging, or wetlands filling and spilling, merging with adjacent wetlands or streams. Intermittent or temporary linear connections (e.g., ephemeral channels, swales, ditches) that connect some wetlands (e.g. Shaw et al. 2012) are often not well documented by NHD (Lang et al. 2012; Fritz et al. 2013) and are difficult to detect with Landsat. Although finer spatial resolution imagery (e.g. QuickBird, Worldview-2 and 3) may expand the types of connectivity captured, these data sources are often collected on-demand and therefore have limited ability to capture temporal changes as landscapes wet up and dry out over time. The advantage of Landsat imagery is that high temporal resolution, combined with large spatial extent, can provide unique insights into the hydrodynamics of stream and wetland landscapes across a range of climatic conditions. In summary, reported degrees of connectivity should be interpreted as a conservative estimate of water body merging (and an incomplete estimate of total surface water connectivity), as it is likely that a portion of wetlands for which no connection was observed have surface connections that are either intermittent or too small to be mapped by NHD (e.g. swales, ephemeral channels) or detected by Landsat.

\section{Results}

\section{Ecoregions}

Ecoregions showed substantial variation in NWI wetland total area and density as well as NHD stream density. The Lowlands and Des Moines Lobe contained fewer NWI wetlands and lower total wetland area, but greater stream density, relative to the other ecoregions (Table 1). The Drift Plains and Missouri Coteau, in contrast, contained a greater number of NWI wetlands and higher total wetland area, but a lower stream density (Table 1). A lower stream density in the Drift Plains and Missouri Coteau was associated with more wetlands classified as WSvc/nc (97\%, Table 1). In contrast, the higher stream density in the Lowlands and Des Moines Lobe was associated with fewer wetlands classified as WSvc/nc (80 and $83 \%$, respectively) (Table 1 ). In general, stream density between the ecoregions was negatively correlated with both the total area of NWI wetlands (Fig. 5) and the percentage of NWI wetlands classified as $\mathrm{WSvc} / \mathrm{nc}$. 


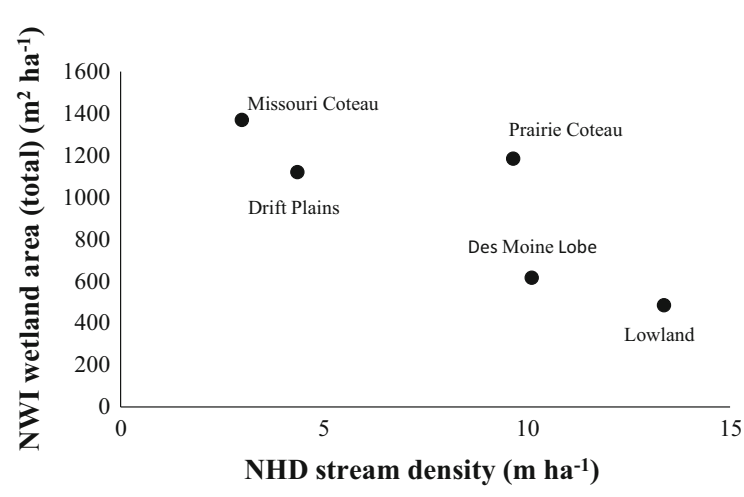

Fig. 5 NWI wetland area (total) as a function of NHD stream density for each of the five ecoregions considered

\section{Patterns of wetland extent}

Actual wetland extent (1) changed from drought to deluge (i.e., the tails of the PHDI CDF curve, Fig. 2), (2) correlated positively with climate indices and runoff, and 3) varied among ecoregions. Wetland extent, as mapped using Landsat, changed substantially between the driest and wettest years. The time series of images represented a wide range of hydrological conditions, from approximately $\operatorname{Pr}(0.06)$ to $\operatorname{Pr}(0.99)$ of wet conditions derived from snow-free monthly conditions (1895-2013), as determined by the PHDI (Fig. 2). The change in area of inundation from the driest year to the wettest year ranged from a $117 \%$ increase in wet area in the Prairie Coteau, to a $388 \%$ increase in wet area in the Lowlands (Table 4). The increase in total wet area with increasingly wet climatic conditions was evident at very coarse scales (see Fig. 6), which shows the change in wetland extent from dry $(\operatorname{Pr}(0.06)(\mathrm{PHDI}))$ to intermediate $(\operatorname{Pr}(0.38)$ (PHDI)) to wet $(\operatorname{Pr}(0.99)$ (PHDI)) conditions across the five ecoregions. The total amount of wetland area was greater using the saturation versus inundation threshold (Fig. 7a). The percentage wetland area (inun) also correlated positively with runoff $\left(\mathrm{mm}\right.$ month $\left.^{-1}\right)$, SRI, and PHDI within all five ecoregions (Table 5).

Wetland-wetland connectivity

The merging of wetlands increased substantially as 1) the wetness threshold became more inclusive (i.e., at the saturation versus the inundation threshold) and 2) overall conditions became wetter (Table 4; Fig. 4). At the inundation threshold, ecoregions showed minimal pair-wise differences in the degree of wetlandwetland connectivity, with the exception of the Lowlands, which showed a lower mean percent of wetland-wetland connectivity (Table 4). The increase in the percentage of merged wetlands between the inundated and saturated thresholds, however, was substantial in all ecoregions (Table 4). In the Drift Plains, for example, the mean percentage of merged wetlands increased from $3.5 \pm 0.7$ to $12.9 \pm 2.6 \%$; in the Des Moines Lobe it increased from $4.2 \pm 0.7$ to $14.3 \pm 1.7 \%$ (Table 4). Wetland-wetland connectivity also increased significantly as conditions became wetter (i.e., total wetland area increased) (Table 6; Fig. 8). For instance, the percentage of wetlands that merged using the saturated threshold over the time series ranged from 1.5 to $30.7 \%$ in the Drift Plains and 7.0-26.8 \% in the Des Moines Lobe (Table 4). Increases in wetland merging were also correlated positively and significantly with monthly runoff and SRI in all five ecoregions under inundated conditions, and all except the Des Moines Lobe (SRI) under saturated conditions (Table 5). The relationship between PHDI and wetland-wetland merging was less consistent, however, with the relationship only significant in two of the five ecoregions, using the inundated threshold (Table 5).

\section{Wetland-stream connectivity}

Similar to wetland-wetland connectivity, the merging of NWI wetlands with streams correlated strongly with total wetland area and changes in wetness conditions. The percentage of WSc/vc was positively and significantly correlated with the percentage of wetland area, using both the inundation and saturation thresholds, in all ecoregions except the Drift Plains (Table 6). In contrast to wetland-wetland connectivity, ecoregions showed significant pair-wise ( $t$ test) differences in the mean percentage of $\mathrm{WSc} / \mathrm{vc}$, with the Lowlands, Des Moines Lobe and Prairie Coteau showing greater wetland-stream connectivity relative to the Missouri Coteau and the Drift Plains (Table 7). The percentage of wetlands merging with streams (WSc/vc) was positively and significantly correlated with monthly runoff in all ecoregions except the Drift Plains (inun) (Table 5). The climate indices performed relatively poor, however, with SRI and PHDI significantly correlated with wetland-stream connectivity (inun) 
Table 4 Mean and range in the percentage of wetland area (using the inundated (inun) and saturated (sat) thresholds), the percentage increase in wetland area compared to the driest year, and the percentage of NWI wetlands that merged with at least one other NWI wetland, by wetness threshold and ecoregion (1990-2011)

\begin{tabular}{|c|c|c|c|c|c|c|}
\hline Ecoregion & $\begin{array}{l}\text { Wetland area } \\
\text { (inun) }(\%)\end{array}$ & $\begin{array}{l}\text { Wetland } \\
\text { area (sat) } \\
(\%)\end{array}$ & $\begin{array}{l}\text { Change in area } \\
\text { from driest } \\
\text { (inun) }(\%)\end{array}$ & $\begin{array}{l}\text { Change in area } \\
\text { from driest } \\
\text { (sat) }(\%)\end{array}$ & $\begin{array}{l}\text { NWI wetlands } \\
\text { merged (inun) }(\%)\end{array}$ & $\begin{array}{l}\text { NWI wetlands } \\
\text { merged (sat) }(\%)\end{array}$ \\
\hline Lowlands & $\begin{array}{l}1.9 \pm 0.2^{4} \\
(0.9-4.3)\end{array}$ & $\begin{array}{l}5.1 \pm 0.5^{3} \\
(2.2-7.9)\end{array}$ & 387.7 & 260.4 & $\begin{array}{l}1.7 \pm 0.4^{2} \\
(0.3-7.0)\end{array}$ & $\begin{array}{l}7.0 \pm 1.3^{3} \\
(2.0-21.9)\end{array}$ \\
\hline Des Moines Lobe & $\begin{array}{l}3.0 \pm 0.2^{3} \\
(2.1-4.6)\end{array}$ & $\begin{array}{l}7.6 \pm 0.6^{2} \\
(4.0-11.2)\end{array}$ & 120.0 & 236.0 & $\begin{array}{l}4.2 \pm 0.7^{1} \\
(1.1-10.7)\end{array}$ & $\begin{array}{l}14.3 \pm 1.7^{1} \\
(7.0-26.8)\end{array}$ \\
\hline Prairie Coteau & $\begin{array}{l}8.7 \pm 0.5^{1} \\
(5.5-11.9)\end{array}$ & $\begin{array}{l}12.4 \pm 0.7^{1} \\
(7.5-16.2)\end{array}$ & 117.4 & 128.1 & $\begin{array}{l}4.8 \pm 0.8^{1} \\
(1.1-9.9)\end{array}$ & $\begin{array}{l}11.3 \pm 1.6^{1,2} \\
(3.6-24.5)\end{array}$ \\
\hline Drift Plains & $\begin{array}{l}5.8 \pm 1.1^{2} \\
(2.1-9.9)\end{array}$ & $\begin{array}{l}10.3 \pm 0.5^{1} \\
(3.3-16.8)\end{array}$ & 375.8 & 460.1 & $\begin{array}{l}3.5 \pm 0.7^{1} \\
(0.2-10.4)\end{array}$ & $\begin{array}{l}12.9 \pm 2.6^{1,2} \\
(1.5-30.7)\end{array}$ \\
\hline Missouri Coteau & $\begin{array}{l}8.8 \pm 0.7^{1} \\
(3.4-12.7)\end{array}$ & $\begin{array}{l}12.1 \pm 0.9^{1} \\
(5.4-17.8)\end{array}$ & 273.3 & 230.1 & $\begin{array}{l}4.0 \pm 0.6^{1} \\
(0.2-8.7)\end{array}$ & $\begin{array}{l}9.3 \pm 1.5^{2,3} \\
(1.5-21.5)\end{array}$ \\
\hline
\end{tabular}

Superscripts indicate significant $(\mathrm{p}<0.05)$ pairwise differences between ecoregions. Plus and minus standard error

in three of the five ecoregions and one of the five ecoregions, respectively (Table 5). Across the five ecoregions, the size of individual wetlands appeared to influence the probability of merging. Although the percentage of NWI wetlands (count) merging with streams was generally less than $25 \%$, regardless of threshold or image wetness, the percentage of total NWI wetland area connected to streams was much greater (Fig. 7b). The mean percentage of NWI wetland area connected using the inundation threshold ranged from $68.9 \pm 0.3 \%$ in the Des Moines Lobe to $29.2 \pm 0.4 \%$ in the Missouri Coteau (Table 7).

Wetlands with variable stream connections

As wetland extent mapped by NWI wetland dataset is meant to represent extent under "average" hydrological conditions (USFWS 2010), its intersection with the stream layer, should capture all wetlands that intersect with streams under "average" hydrological conditions. Correspondingly, when the percentage of wetlands classified as WSvc in a given image was averaged across the time series (i.e., mean hydrological conditions), the percentage tended to be low across all ecoregions (Table 7). However, under deluge conditions, more WSvc/nc merge with streams (i.e. the number of WSvc increases). Using the saturated threshold, for example, up to $8.1 \%$ of the $\mathrm{WSvc} / \mathrm{nc}$ in a single image merged with a stream in the Des Moines Lobe, and up to 7.2, 7.1, 5.0 and 2.4\% in the Lowlands, Prairie Coteau, Drift Plains and Missouri Coteau ecoregions, respectively (Table 7). By area, up to $20.9 \%$ of NWI wetland classified as WSvc/nc merged with a stream in a single image in the Prairie Coteau, for example (Table 7). The percentage of WSvc (by count and area) also responded positively to changing wetness conditions, particularly to increasing runoff and lesser so to SRI (Fig. 9), showing correlation coefficients and significance identical to that shown by the wetland-stream connectivity analysis (Table 5).

When wetlands classified as WSvc were aggregated across the entire time series, this category of wetlands became even more substantial. The percent NWI wetlands classified as a WSvc in at least one image at the saturated threshold, exceeded the percent WSc wetlands in all ecoregions, except the Lowlands. For example, in the Des Moines Lobe, $16.6 \%$ of its wetlands were WSc, or intersected the stream buffer layer, while $18.7 \%$ were WSvc. In the Drift Plains, only $2.6 \%$ of its NWI wetlands were WSc, while $13.0 \%$ were classified as WSvc (Table 7).

\section{Discussion}

This study demonstrated that spatial and temporal variation in wetland extent resulted in variability in surface water connectivity across portions of the Prairie Pothole Region. Similar to the work of others (e.g. 
Fig. 6 Patterns of Landsatderived A) wetland cover (inundated) and B) wetland cover (saturated) for three wetness conditions (left to right), dry $(\operatorname{Pr}(0.06) \mathrm{CDF}$ PHDI) (spring 1990), intermediate $(\operatorname{Pr}(0.38) \mathrm{CDF}$ PHDI) (fall 2006) and wet ( $P r(0.99)$ CDF PHDI) (spring 2011) for p31r27 (top row in $\mathbf{a}$ and $\mathbf{b}$ ) and p29r29 (bottom row in a and b). Note Not all wetlands are visible due to the scale of the images
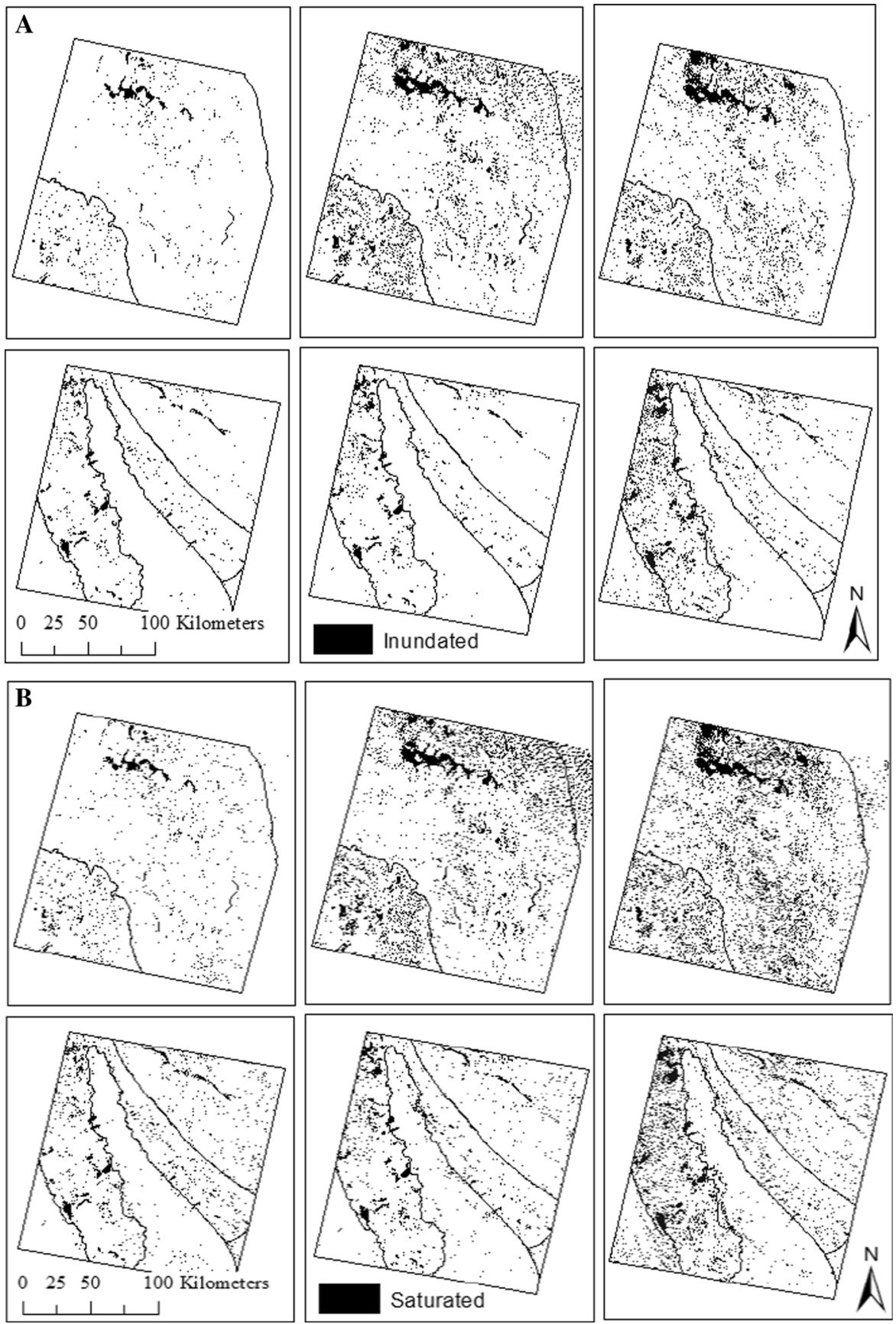

Johnson et al. 2004; Kahara et al. 2009; Zhang et al. 2009; Niemuth et al. 2010; Huang et al. 2011), we found that total wetland area increased substantially from drought to deluge conditions (Table 4) and that total wetland area could be positively correlated to wetness indicators, in this case, PHDI, SRI, and runoff (Table 5). This study went further than previous work to demonstrate that the merging of wetlands and wetlands with streams varied over time and correlated positively with total wetland area (Fig. 8). Despite the limitations regarding the types of connectivity Landsat is able to detect, this approach provided a largely unprecedented view of how wetland-wetland and wetland-stream connectivity changes over time across the PPR. 

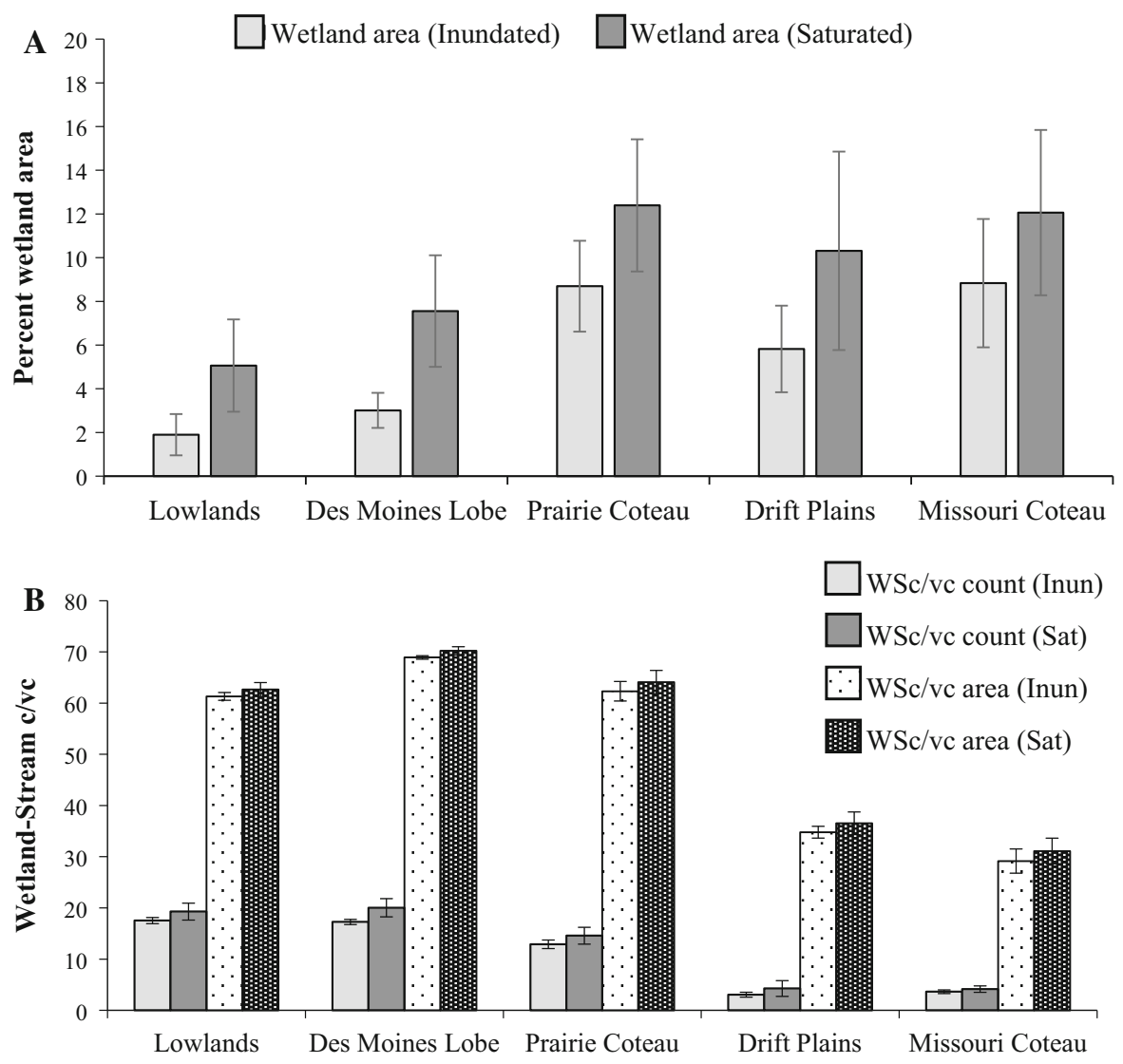

Fig. 7 Ecoregion comparison of a average percent wetland area over the time series, and $\mathbf{b}$ average percent NWI wetlands connected to streams (WSc/vc) over the time series, by count and area. Error bars show plus and minus one standard error

The degree of wetland merging in the PPR was previously explored by Kahara et al. (2009), who similarly found a positive correlation between wetland merging and total wetland surface area in the PPR. Here, we found wetland merging to also be sensitive to the definition of the wet-dry threshold. This is an important factor to consider, as any analysis of "wet" area typically translates a continuous variable, soil moisture, into a binary variable (wet or dry). Because a substantial portion of the saturated area occurred at wetland edges (e.g., mixed Landsat pixels of water and vegetation or vegetated water), wetland merging was greater using the saturation threshold relative to the inundated threshold. Although the saturated threshold improves the identification of small wetland features and vegetated wetland edges, it can also "merge" disconnected wetlands by classifying two adjacent, mixed pixels as water (Muster et al. 2013). The merging of wetlands with streams, in contrast, was found to be less sensitive to the inundation/saturation threshold, at least for this scale and study area. Similarity in the degree of wetland-wetland merging among ecoregions indicates that merging may be independent of within-region variation in wetland density and total wetland area. It also indicates that substantial wetland-wetland interaction occurs even in areas where most NWI wetlands are initially classified as WSvc/nc (e.g., $>97 \%$ of the Drift Plain's NWI wetlands were considered WSvc/nc, but $>30 \%$ of those NWI wetlands merged with at least one other NWI wetland during the wettest images).

Differences in the degree of wetland-stream connectivity between ecoregions is potentially attributable to differences in drainage density (Fig. 5). Variability in stream density among ecoregions, in turn, can be attributed to glacial history. Young moraine landscapes typically contain chaotic drainage networks where streams follow local 
Table 5 Pearson correlation coefficients and significance for patterns of wetland area and wetland connectivity (using the inundation (inun) and saturated (sat) thresholds) in relation to runoff (mm month ${ }^{-1}$ ), the Standardized Runoff Index (SRI), and the Palmer Hydrological Drought Index (PHDI) for each ecoregion

\begin{tabular}{|c|c|c|c|c|c|c|c|c|c|}
\hline Ecoregion & Parameter & $\begin{array}{l}\text { Wetland } \\
\text { area } \\
\text { (inun) }(\%)\end{array}$ & $\begin{array}{l}\text { Wetland } \\
\text { area (sat) } \\
(\%)\end{array}$ & $\begin{array}{l}\text { NWI } \\
\text { wetlands } \\
\text { merged } \\
\text { (inun) } \\
(\%)\end{array}$ & $\begin{array}{l}\text { NWI } \\
\text { wetlands } \\
\text { merged } \\
\text { (sat) }(\%)\end{array}$ & $\begin{array}{l}\text { WSc/vc } \\
\text { count } \\
\text { (inun) }(\%)^{\mathrm{a}}\end{array}$ & $\begin{array}{l}\text { WSc/vc } \\
\text { count } \\
\left(\text { sat) }(\%)^{\mathrm{a}}\right.\end{array}$ & $\begin{array}{l}\mathrm{WSc} / \mathrm{vc} \\
\text { area (inun) } \\
(\%)^{\mathrm{a}}\end{array}$ & $\begin{array}{l}\text { WSc/vc } \\
\text { area } \\
(\text { sat })(\%)^{\mathrm{a}}\end{array}$ \\
\hline \multirow[t]{3}{*}{ Lowlands } & Runoff & $0.82 *$ & $0.63 *$ & $0.85^{*}$ & $0.84 *$ & $0.82 *$ & $0.75^{*}$ & $0.88 *$ & $0.92 *$ \\
\hline & SRI & $0.58 *$ & 0.45 & $0.50 *$ & $0.54 *$ & 0.43 & $0.50 *$ & 0.48 & $0.67 *$ \\
\hline & PHDI & $0.64 *$ & 0.46 & 0.48 & $0.49 *$ & 0.42 & $0.50 *$ & 0.48 & $0.67 *$ \\
\hline \multirow[t]{3}{*}{ Des Moines Lobe } & Runoff & $0.82 *$ & 0.19 & $0.85^{*}$ & $0.75^{*}$ & $0.80 *$ & $0.56^{*}$ & $0.82 *$ & $0.69 *$ \\
\hline & SRI & $0.58 *$ & 0.5 & $0.50 *$ & 0.47 & 0.39 & 0.35 & 0.46 & 0.36 \\
\hline & PHDI & $0.64 *$ & 0.45 & 0.41 & 0.44 & 0.28 & 0.31 & 0.35 & 0.34 \\
\hline \multirow[t]{3}{*}{ Prairie Coteau } & Runoff & $0.74 *$ & $0.75^{*}$ & $0.79 *$ & $0.78^{*}$ & $0.78 *$ & $0.75^{*}$ & $0.63 *$ & $0.69 *$ \\
\hline & SRI & $0.63^{*}$ & $0.71 *$ & $0.58 *$ & $0.59 *$ & $0.58 *$ & $0.57 *$ & $0.53 *$ & $0.64 *$ \\
\hline & PHDI & $0.55^{*}$ & $0.64 *$ & $0.50 *$ & $0.52 *$ & $0.52 *$ & $0.52 *$ & 0.47 & $0.54 *$ \\
\hline \multirow[t]{3}{*}{ Drift Plains } & Runoff & $0.52 *$ & $0.54 *$ & $0.56^{*}$ & $0.61^{*}$ & 0.39 & $0.51 *$ & 0.47 & $0.59 *$ \\
\hline & SRI & $0.77 *$ & $0.69 *$ & $0.54 *$ & $0.55^{*}$ & $0.53 *$ & $0.57 *$ & $0.67 *$ & $0.73 *$ \\
\hline & PHDI & $0.59 *$ & 0.62 & 0.48 & 0.49 & 0.49 & $0.67 *$ & $0.50 *$ & $0.69 *$ \\
\hline \multirow[t]{3}{*}{ Missouri Coteau } & Runoff & $0.55^{*}$ & $0.60 *$ & $0.70 *$ & $0.63 *$ & $0.57 *$ & $0.64 *$ & $0.53 *$ & $0.71 *$ \\
\hline & SRI & $0.80 *$ & $0.81 *$ & $0.73 *$ & $0.63 *$ & $0.65 *$ & $0.71 *$ & $0.72 *$ & $0.78 *$ \\
\hline & PHDI & $0.61 *$ & $0.73 *$ & $0.58^{*}$ & $0.65^{*}$ & 0.44 & $0.70 *$ & 0.49 & $0.61 *$ \\
\hline
\end{tabular}

${ }^{a}$ Pearson correlation values and significance were identical for corresponding WSvc (\%) category

$* \mathrm{p}<0.05$

gradients without a dominating drainage direction. As a landscape ages, it develops a drainage direction and pattern through local and headward erosion, capture, and sedimentation (Ahnert 1996). Drainage density (stream density) in the PPR was greatest in the Lowlands ecoregion, in part because the Wisconsin glacier diverged around the Big Sioux Basin (in the Lowlands ecoregion), leaving the older ( $>20,000 \mathrm{BP}$ ) landscape with a well-developed drainage network (Clayton and Moran 1982). By 11,700 BP the glacier had retreated from the Lowlands, Des Moines Lobe and Prairie Coteau ecoregions- 400 years prior to glacier retreat from the northern two ecoregions (Clayton and Moran 1982)—which may explain lower drainage densities in the northern two ecoregions. Additionally, the northern two ecoregions experience less precipitation (NOAA NCDC 2014), and the rate and density of stream development can also be expected to be influenced by climate (Ahnert 1996).

Wetland characteristics (size, density, shape) across the PPR, and potentially their spatial relationship to streams, are predominately the product of the distribution and type of glacial debris (Flint 1971; Sloan 1972). The Drift Plains, which includes the Devil's Lake area, contains a high number and area of wetlands and lakes, a consequence of ground moraine and outwash, but the flat topography and young age of the landscape has limited drainage development, resulting in the lowest observed rate of wetlands merging with streams among the ecoregions. The Missouri and Prairie Coteau are dominated by dead-ice moraine, or stagnant glacial ice that melted under a sediment layer resulting in a high density of depressions of variable sizes (Kantrud et al. 1989). However, unlike the Missouri Coteau, the Prairie Coteau has a chain of large lakes, formed where there was minimal ice shear (USGS 2013b). These lakes, in addition to a greater stream density and a greater rate of precipitation relative to the Missouri Coteau, might explain why the mean percentage of NWI wetlands merging with streams was greater in the Prairie Coteau relative to the Missouri Coteau. The greater degree of wetlandstream connectivity observed in the Lowlands and Des Moines Lobe, in turn, can be attributed to a better 
Table 6 Pearson correlation coefficients and significance for percentage wetland area (using the inundation (inun) and saturated (sat) thresholds) in relation to the degree of wetland-

\begin{tabular}{|c|c|c|c|c|}
\hline Threshold & Ecoregion & NWI wetlands merged (inun) $(\%)$ & WSc/vc count (inun) $(\%)$ & $\mathrm{WSc} / \mathrm{vc}$ area (inun) $(\%)$ \\
\hline \multirow{5}{*}{$\begin{array}{l}\text { Wetland area } \\
\text { (Inundation) }(\%)\end{array}$} & Lowlands & $0.85 *$ & $0.80 *$ & $0.88^{*}$ \\
\hline & Des Moines Lobe & $0.98^{*}$ & $0.91 *$ & $0.92 *$ \\
\hline & Prairie Coteau & $0.97 *$ & $0.98^{*}$ & $0.96^{*}$ \\
\hline & Drift Plains & $0.88^{*}$ & 0.28 & $0.53 *$ \\
\hline & Missouri Coteau & $0.93 *$ & $0.72 *$ & $0.82 *$ \\
\hline Threshold & Ecoregion & NWI wetlands merged (sat) (\%) & WSc/vc count (sat) $(\%)$ & $\mathrm{WSc} / \mathrm{vc}$ area $(\mathrm{sat})(\%)$ \\
\hline \multirow{5}{*}{$\begin{array}{l}\text { Wetland area } \\
\text { (Saturation) }(\%)\end{array}$} & Lowlands & $0.79 *$ & $0.86^{*}$ & $0.76^{*}$ \\
\hline & Des Moines Lobe & $0.65^{*}$ & $0.83^{*}$ & $0.67 *$ \\
\hline & Prairie Coteau & $0.95^{*}$ & $0.96^{*}$ & $0.90 *$ \\
\hline & Drift Plains & $0.96^{*}$ & $0.82 *$ & $0.82 *$ \\
\hline & Missouri Coteau & $0.92 *$ & $0.95 *$ & $0.82 *$ \\
\hline
\end{tabular}

$* \mathrm{p}<0.05$

Fig. 8 Change in the degree of a wetlandwetland connectivity and b wetland-stream connectivity (WSc/vc) with change in wetland area (inundated), by ecoregion. Linear trend lines are shown with the correlation coefficient wetland merging (NWI wetlands merged) and wetland-stream connectivity $(\mathrm{WSc} / \mathrm{vc}$ ) for each ecoregion 
Table 7 The mean percentage NWI wetlands in each ecoregion that connected to a stream either directly (WSc), through expansion of Landsat-derived wetlands (WSvc), and the sum of

\begin{tabular}{|c|c|c|c|c|c|c|}
\hline Ecoregion & WSc $(\%)$ & $\begin{array}{l}\text { WSc/vc } \\
\text { (inun) }(\%)\end{array}$ & $\begin{array}{l}\text { WSvc }^{\mathrm{a}} \\
\text { (inun) }(\%)\end{array}$ & $\begin{array}{l}\text { WSc/vc } \\
\text { (sat) }(\%)\end{array}$ & $\begin{array}{l}\text { WSvc }^{\mathrm{a}} \text { (sat) } \\
(\%)\end{array}$ & $\begin{array}{l}\text { WSvc (sat) } \\
\text { aggregated }^{b}(\%)\end{array}$ \\
\hline NWI wetland: & Count & & & & & \\
\hline Lowlands & 17.0 & $\begin{array}{l}17.5 \pm 0.1^{1} \\
(17.1-19.3)\end{array}$ & $\begin{array}{l}0.7 \pm 0.2^{2} \\
(0.1-2.8)\end{array}$ & $\begin{array}{l}19.3 \pm 0.4^{1} \\
(17.6-22.9)\end{array}$ & $\begin{array}{l}2.8 \pm 0.5^{2,3} \\
(0.7-7.2)\end{array}$ & 13.8 \\
\hline Des Moines Lobe & 16.6 & $\begin{array}{l}17.3 \pm 0.1^{2} \\
(16.7-18.4)\end{array}$ & $\begin{array}{l}0.8 \pm 0.1^{2} \\
(0.2-2.3)\end{array}$ & $\begin{array}{l}20.0 \pm 0.4^{1} \\
(17.6-23.3)\end{array}$ & $\begin{array}{l}4.2 \pm 0.5^{1} \\
(1.2-8.1)\end{array}$ & 18.7 \\
\hline Prairie Coteau & 11.6 & $\begin{array}{l}12.9 \pm 0.2^{3} \\
(11.8-14.5)\end{array}$ & $\begin{array}{l}1.5 \pm 0.2^{1} \\
(0.3-3.3)\end{array}$ & $\begin{array}{l}14.6 \pm 0.4^{2} \\
(12.5-17.8)\end{array}$ & $\begin{array}{l}3.4 \pm 0.5^{1,2} \\
(1.0-7.1)\end{array}$ & 13.2 \\
\hline Drift Plains & 2.6 & $\begin{array}{l}3.1 \pm 0.1^{5} \\
(2.6-4.7)\end{array}$ & $\begin{array}{l}0.5 \pm 0.1^{2} \\
(0.02-2.2)\end{array}$ & $\begin{array}{l}4.3 \pm 0.4^{3} \\
(2.7-6.8)\end{array}$ & $\begin{array}{l}1.8 \pm 0.4^{3,4} \\
(2.6-5.0)\end{array}$ & 13.0 \\
\hline Missouri Coteau & 3.1 & $\begin{array}{l}3.6 \pm 0.0 .1^{4} \\
(3.1-4.3)\end{array}$ & $\begin{array}{l}0.6 \pm 0.0 .1^{2} \\
(0.02-1.3)\end{array}$ & $\begin{array}{l}4.2 \pm 0.2^{3} \\
(3.2-5.4)\end{array}$ & $\begin{array}{l}1.1 \pm 0.2^{4} \\
(0.2-2.4)\end{array}$ & 4.4 \\
\hline NWI wetland: & Area & & & & & \\
\hline Lowlands & 60.0 & $\begin{array}{l}61.3 \pm 0.2^{3} \\
(60.2-63.2)\end{array}$ & $\begin{array}{l}3.3 \pm 0.5^{3} \\
(0.6-7.9)\end{array}$ & $\begin{array}{l}62.7 \pm 0.3^{3} \\
(61.2-65.7)\end{array}$ & $\begin{array}{l}6.7 \pm 0.8^{2,3} \\
(2.9-14.2)\end{array}$ & 9.7 \\
\hline Des Moines Lobe & 68.4 & $\begin{array}{l}68.9 \pm 0.1^{1} \\
(68.5-69.8)\end{array}$ & $\begin{array}{l}1.8 \pm 0.3^{4} \\
(0.7-4.6)\end{array}$ & $\begin{array}{l}70.2 \pm 0.2^{1} \\
(69.0-71.9)\end{array}$ & $\begin{array}{l}5.9 \pm 0.6^{3} \\
(2.0-11.2)\end{array}$ & 8.3 \\
\hline Prairie Coteau & 58.9 & $\begin{array}{l}62.3 \pm 0.5^{2} \\
(59.5-65.5)\end{array}$ & $\begin{array}{l}8.4 \pm 1.1^{1} \\
(1.6-16.1)\end{array}$ & $\begin{array}{l}64.1 \pm 0.6^{2} \\
(60.4-67.5)\end{array}$ & $\begin{array}{l}12.8 \pm 1.3^{1} \\
(3.8-20.9)\end{array}$ & 13.0 \\
\hline Drift Plains & 32.9 & $\begin{array}{l}34.8 \pm 0.3^{4} \\
(33.1-37.7)\end{array}$ & $\begin{array}{l}2.9 \pm 0.4^{3} \\
(0.4-7.2)\end{array}$ & $\begin{array}{l}36.5 \pm 0.6^{4} \\
(33.5-41.4)\end{array}$ & $\begin{array}{l}5.5 \pm 0.8^{3} \\
(0.9-12.8)\end{array}$ & 13.6 \\
\hline Missouri Coteau & 24.9 & $\begin{array}{l}29.2 \pm 0.6^{5} \\
(25.1-32.3)\end{array}$ & $\begin{array}{l}5.6 \pm 0.8^{2} \\
(0.3-9.7)\end{array}$ & $\begin{array}{l}31.1 \pm 0.6^{5} \\
(27.4-36.0)\end{array}$ & $\begin{array}{l}8.2 \pm 0.8^{2} \\
(3.3-14.8)\end{array}$ & 13.0 \\
\hline
\end{tabular}

Superscripts indicate significant $(\mathrm{p}<0.05)$ pairwise differences between ecoregions. Plus and minus standard error

a The percentage WSvc is calculated from the percentage WSvc/nc, not from all NWI wetlands

b The percent of all NWI wetlands (count and area) that were classified as WSvc in at least one image across the time series

but also to the extent of cultivated crops in these ecoregions (60 and $77 \%$ cultivated crop cover in Lowlands and Des Moines Lobe, respectively) (Homer et al. 2015). Agricultural activity has greatly reduced the number of wetlands across the PPR (Dahl 2014), although its implications for landscape-scale surface water connectivity has not been quantified. In theory, agricultural activity can either increase or decrease aspects of wetland-stream connectivity. For example, ditches, pipes and field tiles can increase connectivity between wetlands and streams (e.g., $18 \%$ of stream length in the Des Moines Lobe is classified as canal/ ditch), whereas filling wetlands and lowering the water table can increase isolation of remaining wetlands (De Laney 1995; Blann et al. 2009).

The three wetness indicators (PHDI, SRI, runoff) showed generally strong associations with both these categories (WSc/vc) over the time series (1990-2011) (using the inundation (inun) and saturated (sat) thresholds) 

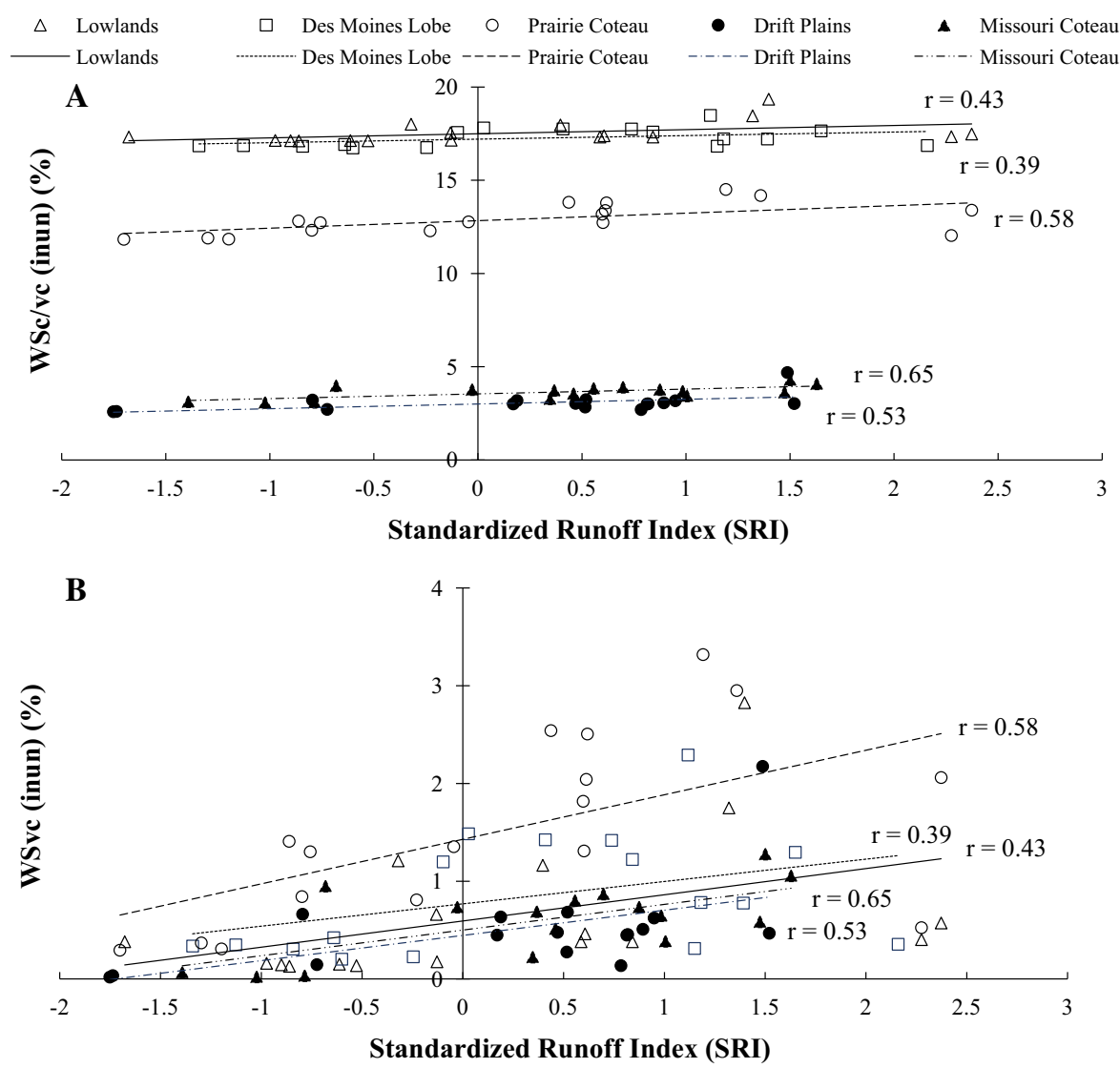

Fig. 9 Change in the a percent NWI wetlands that merged with streams (WSc/vc) and b percent WSvc/nc that showed connections to stream (WSvc), using Landsat-derived wetland

in a less uniform distribution of runoff values over the time series in the Drift Plains and Missouri Coteau, relative to the other wetness indicators (SRI and PHDI), and could have weakened the power of runoff to predict landscape-scale patterns of connectivity within these two ecoregions (Table 5).

A complete analysis of wetland-wetland and wetland-stream connectivity would also need to consider narrow and temporary (e.g. in response to rain events) surface connections, groundwater connections, as well as chemical and biological connections (U.S. EPA 2015). Despite the limitations of our approach, our results support the idea that wetlands occur along a gradient from always connected to rarely connected (EPA 2015). In this analysis the subset of wetlands showing occasional stream connections have been grouped as WSvc or variably connected wetlands. In a static analysis (sensu Tiner 2003) these and other maps (inundated), against the Standardized Runoff Index, by ecoregion. Linear trend lines are shown with the correlation coefficient

wetlands would likely be inappropriately classified. Our work also indicates that patterns of connectivity vary spatially in response to landscape-scale factors, including topography, glacial history, and climate. An improved understanding of the timing and spatial pattern of variable connections is necessary to quantify the distribution of wetlands along a gradient of hydrologic connectivity in diverse landscapes such as the Prairie Pothole Region.

\section{Conclusion}

In conclusion, this study considered both spatial and interannual variability in wetland-wetland and wetland-stream connectivity within five distinct ecoregions in the PPR. Increases in three measures of wetness condition (PHDI, SRI, runoff) correlated 
positively with increases in wetland area, using both inundated and saturated thresholds, but showed variable correlations with wetland merging and the merging of wetlands with streams. Our analysis demonstrated that even regions with a high percentage of wetlands lacking channel connections, such as the Drift Plains and Missouri Coteau, can show substantial degrees of wetland merging under deluge conditions. Despite differences in the density and total area of NWI wetlands, the maximum degree of wetlandwetland connectivity was largely similar across the five ecoregions. The degree of wetland merging, however, responded strongly to changes in overall wetness and the selection of the wet-dry threshold (inundation versus saturation) used to classify Landsat pixels as wetland or upland. Although less-responsive to changes in overall wetness conditions and the selection of a wet-dry threshold, the merging of wetlands with streams varied significantly inter-annually and in particular, spatially. Ecoregions with a greater density of NHD streams showed a higher degree of wetland-stream connectivity. In addition, wetlands that variably merged with streams, when considered cumulatively, exceeded the number of NWI wetlands that intersected streams in most ecoregions. Several studies have called for the need to view wetlands and hydrologic connections over a continuum or varying over time and space (Leibowitz 2003; Leibowitz et al. 2008; Shook et al. 2015; U.S. EPA 2015). The utilization of Landsat imagery in our analysis improved our understanding of spatial and temporal variability in wetland-wetland and wetlandstream connectivity across the PPR, by allowing for a regional analysis over an extended time series. Limitations in the resolution of Landsat, however, call for further work to identify in particular, the frequency and distribution of narrow, temporary surface water connections. Additional work is also needed to improve our understanding of where variable merging of wetlands occurs, whether these types of connections can be predicted, and how they relate to overall surface water connectivity and hydrodynamics on a landscape.

Acknowledgments This project was supported in part by an appointment to the Internship/Research Participation Program at the U.S. Environmental Protection Agency, Office of Research and Development, administered by the Oak Ridge Institute for Science and Education through an interagency agreement between the U.S. Department of Energy and EPA. This work was also funded by the U.S. EPA Office of Research and Development, National Center for Environmental Assessment. We thank Megan Lang and Greg McCarty at USDA for their logistical support, and Scott Leibowitz, Megan Lang, Jay Christensen, Heather Golden and Scot Hagerthey for their comments on earlier versions of the manuscript. We also thank the anonymous reviewers for their comments to improve the manuscript. The views expressed in this manuscript are solely those of the authors and do not necessarily reflect the views or policies of the U.S. EPA. Any use of trade, firm, or product names is for descriptive purposes only and does not imply endorsement by the U.S. Government.

Open Access This article is distributed under the terms of the Creative Commons Attribution 4.0 International License (http:// creativecommons.org/licenses/by/4.0/), which permits unrestricted use, distribution, and reproduction in any medium, provided you give appropriate credit to the original author(s) and the source, provide a link to the Creative Commons license, and indicate if changes were made.

\section{References}

Ahnert F (1996) Introduction to geomorphology. Wiley, New York

Blann KL, Anderson JL, Sands GR, Vondracek B (2009) Effects of agricultural drainage on aquatic ecosystems: a review. Crit Rev Environ Sci Technol 39:909-1001

Brauman KA, Daily GC, Duarte TK, Mooney HA (2007) The nature and value of ecosystem services: an overview highlighting hydrologic services. Annu Rev Environ Resour 32:67-98

Clayton L, Moran SR (1982) Chronology of late Wisconsinan glaciation in middle North America. Quat Sci Rev 1:55-82

Comer P, Goodin K, Tomaino A, Hammerson G, Kittel G, Menard S, Nordman C, Pyne M, Reid M, Sneddon L, Snow K (2005) Biodiversity values of geographically isolated wetlands in the United States. Natureserve, Arlington. http://www.natureserve.org/library/isolated_wetlands_05/ isolated_wetlands.pdf

Cook BJ, Hauer FR (2007) Hydrologic connectivity on water chemistry, soils, and vegetation structure and function in an intermontane depressional wetland landscape. Wetlands 27(3):719-738

Cowardin LM, Carter V, Golet FC, LaRoe ET (1979) Classification of wetlands and deepwater habitats of the United States. U.S. Department of the Interior, Fish and Wildlife Service, Washington, D.C. https://www.fgdc.gov/standards/ projects/FGDC-standards-projects/wetlands/nvcs-2013

Dahl TE (2014) Status and trends of prairie wetlands in the United States 1997 to 2009. U.S. Department of the Interior; Fish and Wildlife Service, Ecological Services, Washington, D.C. http://www.fws.gov/wetlands/ Documents/Status-and-Trends-of-Prairie-Wetlands-in-theUnited-States-1997-to-2009.pdf

Dai A, Trenberth KE, Qian T (2004) A global dataset of Palmer drought severity index for 1870-2002: relationship with soil moisture and effects of surface warming. J Hydrometerol 5:1117-1130 
De Laney TA (1995) Benefits to downstream flood attenuation and water quality as a result of constructed wetlands in agricultural landscapes. J Soil Water Conserv 50(6):620-626

Flint RF (1971) Glacial and quaternary geology. Wiley, New York

Fritz KM, Hagenbuch E, D’Amico E, Reif M, Wigington PJ Jr, Leibowitz SG, Comeleo RL, Ebersole JL, Nadeau TL (2013) Comparing the extent and permanence of headwater streams from two field surveys to values from hydrologic databases and maps. J Am Water Resour Assoc (JAWRA) 49:867-882

Frohn RC, D'Amico E, Lane C, Autry B, Rhodus J, Liu H (2012) Multi-temporal sub-pixel Landsat ETM+ classification of isolated wetlands in Cuyahoga County, Ohio, USA. Wetlands 32:289-299

Green AA, Berman M, Switzer P, Craig MD (1988) A transformation for ordering multispectral data in terms of image quality with implications for noise removal. IEEE Trans Geosci Remote Sens 26(1):65-74

Homer C, Dewitx J, Yang L, Jin S, Danielson P, Xian G, Coulston J, Herold N, Wickham J, Megown K (2015) Completion of the 2011 National Land Cover Database for the conterminous United States-representing a decade of land cover change information. Photogrammetric Engineering and Remote Sensing 81:345-354. http://www. mrlc.gov

Huang S, Dahal D, Young C, Chander G, Liu S (2011) Integration of Palmer drought severity index and remote sensing data to simulate wetland water surface from 1910 to 2009 in Cottonwood Lake area, North Dakota. Remote Sens Environ 115:3377-3389

Johnson WC, Boettcher SE, Poiani KA, Guntenspergen G (2004) Influence of weather extremes on the water levels of glaciated prairie wetlands. Wetlands 24:385-398

Kahara SN, Mockler RM, Higgins KF, Chipps SR, Johnson RR (2009) Spatiotemporal patterns of wetland occurrence in the prairie pothole region of eastern South Dakota. Wetlands 29(2):678-689

Kantrud HA, Krapu GL, Swanson GA (1989) Prairie basin wetlands of the Dakotas: a community profile. U.S. Fish and Wildlife Service Biological Report 85(7.28). http:// www.nwrc.usgs.gov/techrpt/85-7-28.pdf

Kingstse M, Chen LC (2014) Standardized Runoff Index dataset: 1979-2012. National Oceanic and Atmospheric Administration (NOAA) National Weather Service. http:// www.cpc.ncep.noaa.gov/products/Drought/Monitoring/ sri3.shtml

Lane CR, D'Amico E (2010) Calculating the ecosystem service of water storage in isolated wetlands using LiDAR in north central Florida, USA. Wetlands 30:967-977

Lane CR, D'Amico E, Autrey B (2012) Isolated wetlands of the southeastern United States: abundance and expected condition. Wetlands 32:753-767

Lang M, McDonough O, McCarty G, Oesterling R, Wilen B (2012) Enhanced detection of wetland-stream connectivity using LiDAR. Wetlands 32:461-473

Leibowitz SG (2003) Isolated wetlands and their functions: an ecological perspective. Wetlands 23(3):517-531

Leibowitz SG, Vining KC (2003) Temporal connectivity in a prairie pothole complex. Wetlands 23:13-25
Leibowitz SG, Wigington PJ, Rains MC, Downing DM (2008) Non-navigable streams and adjacent wetlands: addressing science needs following the Supreme Court's Rapanos decision. Front Ecol Environ 6(7):364-371

Liu G, Schwartz FW (2011) An integrated observational and model-based analysis of the hydrologic response of prairie pothole systems to variability in climate. Water Resour Res 47:W02504

Ludden AP, Frink DL, Johnson DH (1983) Water storage capacity of natural wetland depressions in the Devils Lake Basin of North Dakota. J Soil Water Conserv 38:45-48

Masek JG, Vermote EF, Saleous N, Wolfe R, Hall EF, Huemmrich F et al (2006) A Landsat surface reflectance data set for North America, 1990-2000. Geosci Remote Sens Lett 3:68-72

McIntyre NE, Wright CK, Swain S, Hayhoe K, Liu G, Schwartz FW, Henebry GM (2014) Climate forcing of wetland landscape connectivity in the Great Plains. Front Ecol Environ 12(1):59-64

Millennium Ecosystem Assessment (2005) Ecosystems and human well-being: wetlands and water synthesis. World Resources Institute, Washington. http://www.mill enniumassessment.org/documents/document.358.aspx.pdf

Mitsch WJ, Gosselink JG (2000) Wetlands, 3rd edn. Wiley, New York

Mushet DM, Calhun AJK, Alexander LC, Cohen MJ, DeKeyser ES, Fowler L, Lane CR, Lang MW, Rains MC, Walls SC (2015) Geographically isolated wetlands: rethinking a misnomer. Wetlands 35(3):423-431

Muster S, Heim B, Abnizova A, Boike J (2013) Water body distributions across scales: a remote sensing based comparison of three arctic tundra wetlands. Remote Sens 5(4):1498-1523

Niemuth ND, Wangler B, Reynolds RE (2010) Spatial and temporal variation in wet area of wetlands in the prairie pothole region of North Dakota and South Dakota. Wetlands 30:1053-1064

NOAA National Climatic Data Center (2014) Data Tools: 1981-2010 Normals. http://www.ncdc.noaa.gov/cdo-web/ datatools/normals

Omernik JM, Griffith GE (2014) Ecoregions of the conterminous United States: evolution of a hierarchical spatial framework. Environ Manag 54(6):1249-1266

Philips RW, Spence C, Pomeroy JW (2011) Connectivity and runoff dynamics in heterogeneous basins. Hydrol Process 25:3061-3075

R Core Team (2014) R: a language and environment for statistical computing. R Foundation for statistical computing, Vienna. http://www.R-project.org/

Rains MC, Fogg GE, Harter T, Dahlgren RA, Williamson RJ (2006) The role of perched aquifers in hydrological connectivity and biogeochemical processes in vernal pool landscapes, Central Valley, California. Hydrol Process 20:1157-1175

Rains MC, Dahlgren RA, Fogg GE, Harter T, Williamson RJ (2008) Geological control of physical and chemical hydrology in California vernal pools. Wetlands 28:347-362

Ruiz L, Parikh N, Heintzman LJ, Collins SD, Starr SM, Wright CK, Henebry GM, van Gestel N, McIntyre NE (2014) Dynamic connectivity of temporary wetlands in the southern Great Plains. Landsc Ecol 29:507-516 
Sass GZ, Creed IF (2008) Characterizing hydrodynamics on boreal landscapes using archived synthetic aperture radar imagery. Hydrol Process 22:1687-1699

Shaw DA, Vanderkamp G, Conly FM, Pietroniro A, Martz L (2012) The fill-spill hydrology of prairie wetland complexes during drought and deluge. Hydrol Process 26:3147-3156

Shaw DA, Pietroniro A, Martz LW (2013) Topographic analysis for the prairie pothole region of Western Canada. Hydrol Process 27:3105-3114

Shook K, Pomeroy J, van der Kamp G (2015) The transformation of frequency distributions of winter precipitation to spring streamflow probabilities in cold regions; case studies from the Canadian Prairies. J Hydrol 521:395-409

Shukla S, Wood AW (2008) Use of a standardized runoff index for characterizing hydrologic drought. Geophys Res Lett 35:L02405

Sloan CE (1972) Ground-water hydrology of Prairie Potholes in North Dakota. Geological Survey Professional Paper 585-C. U.S. Department of the Interior, U.S. Geological Survey, Washington, DC. http://pubs.usgs.gov/pp/0585c/ report.pdf

Sorenson L, Goldberg R, Root T, Anderson M (1998) Potential effects of global warming on waterfowl populations breeding in the northern Great Plains. Clim Change 40:343-369

Tiner RW (2003) Estimated extent of geographically isolated wetlands in selected areas of the United States. Wetlands 23:636-652

Tromp-van Meerveld HJ, McDonnell JJ (2006) Threshold relations in subsurface stormflow: 2. The fill and spill hypothesis. Water Resour Res 42:W02411
Turin G (1960) An introduction to matched filters. IRE Trans Inf Theory 6:311-329

U.S. EPA (2015) Connectivity of streams and wetlands to downstream waters: a review and synthesis of the scientific evidence. U.S. Environmental Protection Agency, Washington, DC, EPA/600/R-14/475F. http://cfpub.epa.gov/ ncea/cfm/recordisplay.cfm?deid $=296414$

U.S. Fish and Wildlife Service (2010) National Wetlands Inventory website. U.S. Department of the Interior, Fish and Wildlife Service, Washington, D.C. http://www.fws. gov/wetlands/

U.S. Geological Survey (2000) The national hydrography dataset concepts and content. http://nhd.usgs.gov/chapter1/ chp1_data_users_guide.pdf

U.S. Geological Survey (2013a). The National Hydrography Dataset (NHD). U.S. Geological Survey, Reston, Virginia. ftp://nhdftp.usgs.gov/DataSets/Staged/States/FileGDB/ HighResolution/

U.S. Geological Survey (2013b). Ecoregions of North Dakota and South Dakota. U.S. Geological Survey, Northern Prairie Wildlife Research Center, Sioux Falls, South Dakota

Whigham DF, Jordan TE (2003) Isolated wetlands and water quality. Wetlands 23:541-549

Wilcox BP, Dean DD, Jacob JS, Sipocz A (2011) Evidence of surface connectivity for Texas Gulf Coast depressional wetlands. Wetlands 31:451-458

Winter TC, LaBough JW (2003) Hydrological considerations in defining isolated wetlands. Wetlands 23(3):532-540

Zhang B, Schwartz FW, Liu G (2009) Systematics in the size structure of prairie pothole lakes through drought and deluge. Water Resour Res 45:W04421 